\title{
LAKE WATER QUALITY FOR HUMAN USE AND TOURISM IN CENTRAL ITALY (ROME)
}

\author{
EDOARDO CALIZZA ${ }^{1}$, FEDERICO FIORENTINO $^{1}$, GIULIO CAREDDU $^{1}$, \\ LORETO ROSSI $^{1,2}$ \& MARIA LETIZIA COSTANTINI ${ }^{1,2}$ \\ ${ }^{1}$ Department of Environmental Biology, Sapienza University of Rome, Italy \\ ${ }^{2}$ CoNISMa, Italy
}

\begin{abstract}
The lakes in the Italian region of Lazio, and in particular Lake Bracciano, have suffered due to reduced rainfall during the most recent years $(1264.8 \mathrm{~mm}$ in $2014 \mathrm{vs} 308.4 \mathrm{~mm}$ in 2015 and $883.6 \mathrm{~mm}$ in 2016 in Lake Bracciano). Moreover, Lake Bracciano exhibits both a direct water withdrawal (as drinkable water for the city of Rome and several other towns), and an indirect one, by the groundwaters, for agriculture. The $1.5 \mathrm{~m}$ water reduction, never observed in the last two decades, bared over $10 \mathrm{~m}$ of the littoral zone with the consequent exposition of gravel shores, trashes and reduction of the bottom areas involved in the denitrification process. This condition poses a threat to the ecosystem and to the human profits in term of eutrophication, healthy water loss, ship handling difficulties, touristic boats included, and tourism decline. In a previous investigation, we sampled the epilithic algae in the littoral zone of Lake Bracciano and estimated their nitrogen isotopic signature $\left(\delta^{15} \mathrm{~N}\right)$. We highlighted the presence of diffuse organic and inorganic nitrogen inputs not intercepted by the wastewater collection system. These inputs, in synergy with water-level reduction, are able to undermine the ecosystem structure and health. In this paper, we show the nitrogen isotopic signatures, and their sources, as euros gained by parking meters for non-residents. We highlight the role of the touristic pressure not intercepted by the wastewater treatment plant in terms of $\delta^{15} \mathrm{~N}$ increase during the most critical season (i.e. summer). The results show strong increases of euros gained and consequent $\delta^{15} \mathrm{~N}$ signature increases $\left(9 \%<\delta^{15} \mathrm{~N}<17 \%\right.$ ) from the end of June to the middle of August. We provide evidence supporting the need to adopt management policies to preserve the ecosystem services and related human health and earnings.

Keywords: Epilithon, nitrogen inputs, $\delta^{15} \mathrm{~N}$, volcanic lake.
\end{abstract}

\section{INTRODUCTION}

Lake ecosystems represent impressive and irreplaceable sources of ecosystem services, including drinkable water, irrigation water for agriculture, fishing and leisure activities [1]-[3]. On the other hand, human activities can determine nutrient inputs, especially nitrogen and phosphorus, in the water body [4]-[9] and turn them to pressures. In lacustrine ecosystems nitrogen enrichment can enhance algal blooms with severe consequences for ecosystem, human health and profits [10]-[12]. Therefore, the identification of the organic/inorganic origin and seasonal dynamics of inputs is essential in order to establish the proper management initiatives.

Lake Bracciano [13]-[16], located north of Rome in the Central Italian Volcanic Lake District (CIVOILD), represents an interesting case of study since it: (1) is a regional park since 1999, (2) exhibits several human activities (from agriculture and fisheries to recreation and tourism especially in Summer), (3) is the water source for the CO.B.I.S. (Consorzio del Bacino Idrico Sabatino, which includes the towns of Anguillara-Sabazia, Bracciano, Manziana, Oriolo-Romano and Trevignano Romano) population and (4) is the main drinking water reservoir for the city of Rome, by direct water extraction [17]. The latter two points are particularly crucial. As a matter of fact, direct (as drinkable water) and indirect (for agriculture) withdrawals together with rainfall reductions $(1264.8 \mathrm{~mm}$ in 2014 vs. $308.4 \mathrm{~mm}$ in 2015 and $883.6 \mathrm{~mm}$ in 2016), produced an alarming water level decline, never observed 
in the last decades [18]. In fact, the water level has reduced by 1.5 meters, thus exposing 10 meters of bare littoral zone [19]. This alarming condition of the hydrological balance can affect the benthic community [20] and the denitrification processes [21] with consequent nitrogen accumulation, which, in turn, can promote algal blooms [22] and boost the deterioration of water quality and ecosystem services.

In a previous work [23], we were able to identify the different types of nitrogen inputs (both organic and inorganic) affecting the Lake Bracciano littoral zone and their space-time dynamics (related to the different human activity magnitudes along the whole perimeter in a yearlong monitoring study), by the nitrogen isotopic signature of the epilithic association, $\delta^{15} \mathrm{~N}$. Epilithic $\delta^{15} \mathrm{~N}$ turned out to be a very flexible, easy to collect and manipulate, and species-specific independent monitoring tool [23]. Using the $\delta^{15} \mathrm{~N}$ values, we were able to identify the organic impacted area in the western littoral side of the lake. This side, in summer, was characterized by a high touristic pressure, partially not intercepted by the wastewater collection system, reflected by $\delta^{15} \mathrm{~N}$ values over the threshold of the $6 \%$ and $9 \%$ and therefore classifiable, respectively, as moderate organic and highly organic impacted [23].

Aims of this paper are to quantify the relationship between organic $\delta^{15} \mathrm{~N}$ and tourism activities in this zone (in terms of parking meters earnings), to estimate the $\delta^{15} \mathrm{~N}$ values especially in July and August and to provide reasonable evidence for the pressing needs for management policies of Lake Bracciano especially during the summer season.

\section{MATERIALS AND METHODS}

Lake Bracciano ( $42^{\circ} 07^{\prime} 16^{\prime \prime} \mathrm{N}$; $\left.12^{\circ} 13^{\prime} 55^{\prime \prime} \mathrm{E}\right)$ is a volcanic lake located in central Italy, $32 \mathrm{~km}$ northwest of Rome (Lazio, Italy). It has a surface area of $57 \mathrm{~km}^{2}$ and a perimeter of about $31.5 \mathrm{~km}$. Its elevation is $164 \mathrm{~m}$ a.s.l. and its maximum depth is $165 \mathrm{~m}$. The lake is oligomesotrophic, and warm monomictic from May to October and homothermic from November to February [13]. It has a theoretical renewal time of 137 years, and is used as a drinking water reservoir for the city of Rome and the Vatican State. To prevent the local urban wastewater discharges in the water body a centralized collection system was built in the early 80 s. This collection system is able to serve 40,000 inhabitants, but the present-day CO.B.I.S. population is around 49,000 inhabitants and increases in summer [24].

The combined action of climate change and water extraction produces dangerous water level variations that drastically change the shape of the shoreline and inshore bathymetry. Since 1999, the lake and its surroundings have been part of the regional park of Bracciano Martignano. Due the presence of a high touristic enterprise concentration [23] we chose three sampling sites (namely, A, B and C; Fig. 1) in the western side of the lake, characterized by a high level of anthropic activities on the lakeshore (bar, restaurants, beach resorts etc.). Moreover, we considered the earnings of four parking meters, in parking areas on the lakeshore used by non-residents, to be a proxy for tourism pressure. Earnings were measured weekly from the beginning of May to the end of August. The cost of parking was $€ 1$ per hour per car. The parking meters do not operate from October to March.

\subsection{Field procedures}

Samplings were performed from June 2015 to March 2016 (six sampling dates). In each sampling date and at each sampling site (three sites: A, B and C), three small patches $(5 \times 5 \mathrm{~cm})$ of epilithic association were carefully scraped with a single-edge razor from three similar and smooth volcanic rocks (approximately $30 \times 15 \times 7 \mathrm{~cm}$ ) from shallow waters. Samples were stored in Petri plates and conserved in ice for transport in laboratory. 


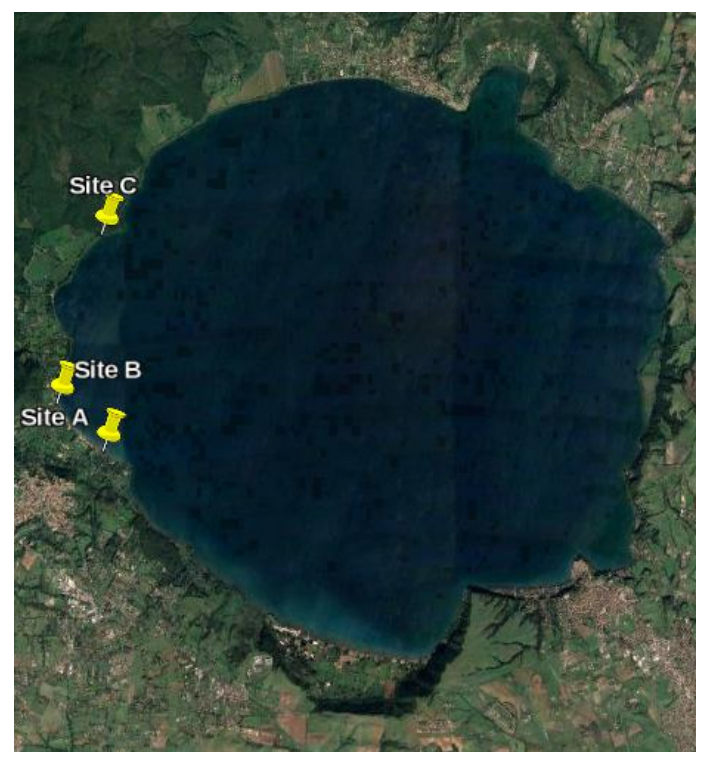

Figure 1: Location of the three sampling sites (A, B, C) in Lake Bracciano.

\subsection{Laboratory procedures}

Samples were conserved at $-80^{\circ} \mathrm{C}$ before freeze-drying for 24 hours and ground to a fine homogenous powder using a ball mill (Fritsch Mini-Mill Pulverisette 23 with a zirconium oxide ball). For each epilithic sample, two replicates $(2.0 \pm 0.2 \mathrm{mg})$ were sub-sampled and pressed into ultra-pure tin capsules and analysed using an Elementar Vario Micro-Cube elemental analyser (Elementar Analysensysteme GmbH, Germany) coupled with an IsoPrime100 isotope mass ratio spectrometer (Isoprime Ltd., Cheadle Hulme, UK). The obtained nitrogen $(\mathrm{N})$ stable isotope ratios $(15 \mathrm{~N}: 14 \mathrm{~N})$ were expressed in $\delta$ units, as parts per thousand deviations from international standards (atmospheric N2), in accordance with the following equations: $\delta \mathrm{R}(\%)=\left[(\mathrm{RSAMPLE}-\mathrm{RSTANDARD}) /(\mathrm{RSTANDARD}) * 10^{3}\right]$ [25], where $\mathrm{R}$ is the heavy-to-light isotope ratio of the element. The internal laboratory standard was IAEA-600 Caffeine. Measurement errors were found to be typically smaller than $\pm 0.05 \%$. In accordance with Cole et al. [26], Derse et al. [27] and Kendall et al. [28], four impact classes were identified: 'inorganic input' $\left(\delta^{15} \mathrm{~N}<3 \%\right.$ ), 'non-impacted' $\left(3 \% \leq \delta^{15} \mathrm{~N} \leq 6 \%\right)$, 'moderate organic input' $\left(6 \%<\delta^{15} \mathrm{~N} \leq 9 \%\right)$ and 'high organic input' $\left(\delta^{15} \mathrm{~N}>9 \%\right)$.

\subsection{Statistical analysis}

An ANOVA (significance level $\alpha=0.05$ ) was applied to test the presence of significant differences in euro earnings of the parking meters between May, June, July and August, followed by a Tukey post-hoc test. We then performed a linear regression between the earnings of the parking meters and the days from starting date. The records had a time lag of 7 days, so we considered the first record as day 0 and the last one as day 119 (18 weeks). We therefore estimated the $\delta 15 \mathrm{~N}$ values during the whole study period as a function of average euros earned according with our previous study [23]. 


\section{RESULTS}

Results show an increasing anthropic presence in the lake during summer as indicated by the increasing amount of the euro earnings (Fig. 2(a) and (b); ANOVA, F = 41.94, $p<0.001$ ) and a consequent increase of organic $\mathrm{N}$ input as indicated by the estimated $\delta^{15} \mathrm{~N}$ values. In particular, the anthropic pressure abruptly increased at the end of June (during a public holiday for the entire municipality of Rome, $29^{\text {th }}$ June) and July, and remained high in August with a peak on $15^{\text {th }}$ August (a national public holiday; Fig. 2(a) at day 105). The Tukey posthoc test (Fig. 2(b)) found statistically significant differences $(p<0.001)$ between May/June and July/August, but not between May and June and between July and August. The linear regression between the euros earnings and the days from the beginning of records showed a strong linear increasing (Fig. 3(a); $\left.t=6.083, p<0.001, R^{2}=0.68\right)$ with a slope of $7.04( \pm 1.16)$ euros*day and an intercept of $105.21( \pm 80.68)$. Estimated $\delta^{15} \mathrm{~N}$ signatures from the $56^{\text {th }}$ day (end of June) to the $119^{\text {th }}$ day (end of August), were always over the threshold of $9 \%$, and then classifiable as typically high organic input signatures (Fig. 3(b)).

\section{DISCUSSION}

It is widely recognized that tourism represents a strong pressure for various aquatic ecosystems, both marine [29], [30] and freshwater [5], [6], [10]. On the other hand, a lack of knowledge of its effect in lacustrine ecosystems persists and the lake littoral zone might be a useful zone to sample in order to intercept the touristic pressure [31], [32]. Moreover, physicochemical environmental monitoring methods only provide snapshots of ecosystem trophic conditions, and therefore several sampling dates are required and pulse inputs, like the first nitrogen isotopic peak observed in our study, are likely to be missed [33] especially if they occur during holydays. On the contrary stable isotopes analysis is a flexible and reliable tool employed in trophic ecology and environmental monitoring since the stable nitrogen isotope ratio $\left(\delta^{15} \mathrm{~N}\right)$, as sensitive indicator of $\mathrm{N}$ sources in many ecosystems, is rapidly integrated, similarly to the radioisotopes, in fast growing organisms and algae and, thus, in the benthic food webs [34]-[41].

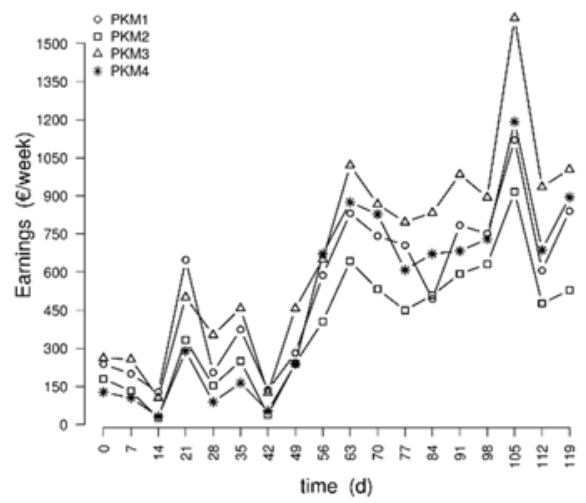

(a)

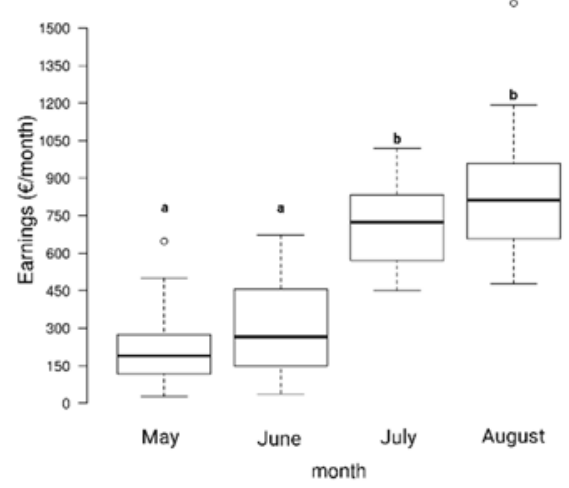

(b)

Figure 2: Euros earned by parking meters. (a) The lines represent the euro amounts earned by each parking meters, PKM1, PKM2, PKM3, PKM4, for non-residents from May (day 0) to August (day 119); (b) Box plots of the earnings of parking meters during the observed months. Different letters above the box plot indicate significant differences between months (Tukey post hoc test, $\alpha=0.05$ ). 


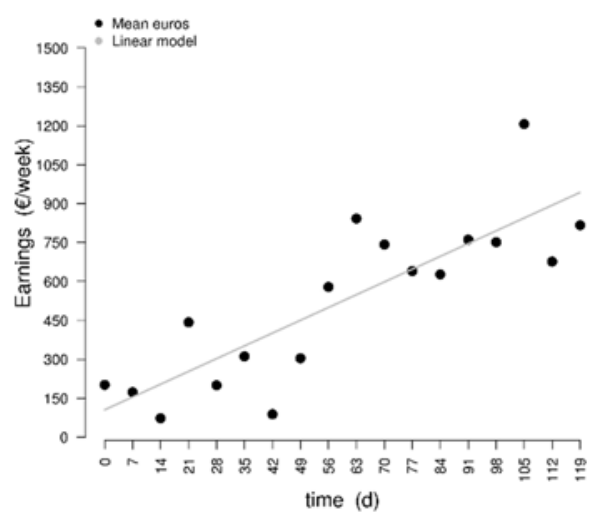

(a)

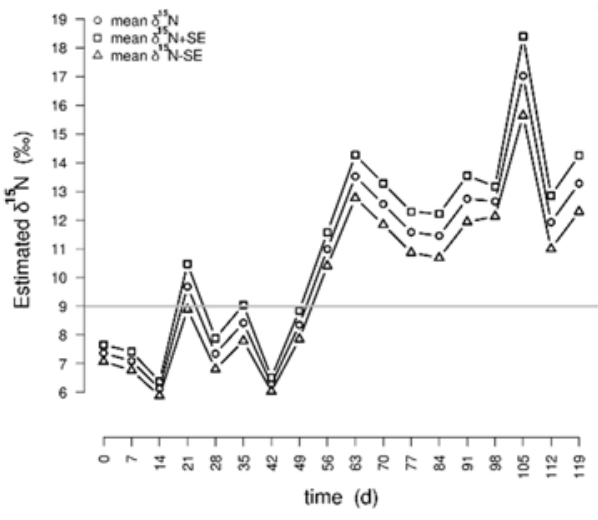

(b)

Figure 3: $\quad$ Euros and estimated $\delta^{15} \mathrm{~N}(\%)$ trends. (a) Plot of linear model, significance level $\alpha=0.05$, between mean euros earned by the four parking meters and days; (b) Plot of estimated mean $\delta^{15} \mathrm{~N}(\%)$ : circle $=$ mean $\delta^{15} \mathrm{~N}$ signatures, square $=$ mean $\delta^{15} \mathrm{~N}+$ standard error $(\mathrm{SE})$, triangle $=$ mean $\delta^{15} \mathrm{~N}-$ standard error (SE). The high organic signature threshold $(9 \%$ ) is reported.

Our results indicate that summer is a critical season, in terms of organic nitrogen inputs, for Lake Bracciano. As a matter of fact, from the beginning of May to the end of June the parking meters for the non-residents earned similar amounts, and, from the end of June to the end of August, globally showed a linear increasing trend in their incomes. Moreover, in the period considered, there were two peaks characterized by abrupt increases of anthropic pressure on the lake shores both related to public holydays ( $29^{\text {th }}$ July and $15^{\text {th }}$ August). As a consequence of the higher human pressure, in May and June the estimated $\delta^{15} \mathrm{~N}$ signatures were above the non-impacted range whereas during the summer season (late June, July and August), the estimated $\delta^{15} \mathrm{~N}$ signatures were in the high organic input range, with a maximum $\delta^{15} \mathrm{~N}$ value comprised between $15.64 \%<\delta^{15} \mathrm{~N}<18.39 \%$. Such nitrogen isotopic signatures can be considered as the worst case, assuming a high response degree of $\delta^{15} \mathrm{~N}$ signatures to increasing parking meter earnings (i.e. a high response degree of nitrogen isotopic signatures and touristic pressure). Similar isotopic values, associated with tourism, had been detected in surface sediments of eutrophic lakes [42] and in marine macroalgae [29], [43], [44], therefore providing a proxy of the effects of tourism on water bodies.

\section{CONCLUSIONS}

Lake Bracciano already suffers from the effect of climate change and direct water extraction and our results indicated that, during the late summer season (July and August), the nonresidents anthropic pressure on Lake Bracciano shores rapidly increased, threatening the water healthiness and ecosystem health. The high estimated $\delta^{15} \mathrm{~N}$ signatures were over the threshold of high organic inputs in late June, July and August, in accordance with our previous work [23].

For its high naturalistic, social and economic values, there is the necessity of management policies adoption and, primarily, an "upgrade" of the wastewater treatment plant compared to the current and inadequate 40,000 units, especially where the concentration of touristic 
activities is high, and especially during the public holydays, when the touristic pressure and related $\delta^{15} \mathrm{~N}$ signatures reached their respective peaks.

\section{AKNOWLEDGEMENTS}

This research was supported by Sapienza Starting Grants (“Avvio alla Ricerca”) 2015-E. Calizza, PRNA 2013-L. Rossi and PNRA 2015-M.L. Costantini, ATENEO 2015 Costantini.

\section{REFERENCES}

[1] Page, T., Heathwaite, A.L., Moss, B., Reynolds, C., Beven, K J., Pope, L. \& Willows, R., Managing the impacts of nutrient enrichment on river systems: Dealing with complex uncertainties in risk analyses. Freshwater Biology, 57(s1), pp. 108-123, 2012.

[2] Pimentel, D., Berger, B., Filiberto, D., Newton, M., Wolfe, B., Karabinakis, E., Clark, S., Poon, E., Abbett, E. \& Nandagopal, S., Water resources: Agricultural and environmental issues. BioScience, 54(10), pp. 909-918, 2004.

[3] Smith, V.H., Eutrophication of freshwater and coastal marine ecosystems a global problem. Environmental Science and Pollution Research, 10(2), pp. 126-139, 2003.

[4] Derse, E., Knee, K.L., Wankel, S.D., Kendall, C., Berg, C.J. \& Paytan, A., Identifying sources of nitrogen to Hanalei Bay, Kauai, utilizing the nitrogen isotope signature of macroalgae. Environmental Science \& Technology, 41(15), pp. 5217-5223, 2007.

[5] di Lascio, A., Rossi, L., Carlino, P., Calizza, E., Rossi, D. \& Costantini, M.L., Stable isotope variation in macroinvertebrates indicates anthropogenic disturbance along an urban stretch of the river Tiber (Rome, Italy). Ecological Indicators, 28, pp. 107-114, 2013.

[6] Galloway, J.N., Aber, J.D., Erisman, J.W., Seitzinger, S.P., Howarth, R.W., Cowling, E.B. \& Cosby, B.J., The nitrogen cascade. Bioscience, 53(4), pp. 341-356, 2003.

[7] Matson, P.A., Parton, W.J., Power, A.G. \& Swift, M.J., Agricultural intensification and ecosystem properties. Science, 277(5325), pp. 504-509, 1997.

[8] Vilmi, A., Karjalainen, S.M., Landeiro, V.L. \& Heino, J., Freshwater diatoms as environmental indicators: Evaluating the effects of eutrophication using species morphology and biological indices. Environmental Monitoring and Assessment, 187(5), pp. 1-10, 2015.

[9] Vitousek, P.M., Aber, J.D., Howarth, R.W., Likens, G.E., Matson, P.A., Schindler, D.W., Schlesinger, W.H. \& Tilman, D.G., Human alteration of the global nitrogen cycle: Sources and consequences. Ecological Applications, 7(3), pp. 737-750, 1997.

[10] Xu, H., Paerl, H.W., Qin, B., Zhu, G. \& Gao, G., Nitrogen and phosphorus inputs control phytoplankton growth in eutrophic Lake Taihu, China. Limnology and Oceanography, 55(1), pp. 420-432, 2010.

[11] Jankowski, K., Schindler, D.E. \& Holtgrieve, G.W., Assessing nonpoint-source nitrogen loading and nitrogen fixation in lakes using $\delta^{15} \mathrm{~N}$ and nutrient stoichiometry. Limnology and Oceanography, 57(3), pp. 671-683, 2012.

[12] Hadwen, W.L., Bunn, S.E., Arthington, A.H. \& Mosisch, T.D., Within-lake detection of the effects of tourist activities in the littoral zone of oligotrophic dune lakes. Aquatic Ecosystem Health \& Management, 8(2), pp. 159-173, 2005.

[13] Ferrara, O., Vagaggini, D. \& Margaritora, F.G., Zooplankton abundance and diversity in Lake Bracciano, Latium, Italy. Journal of Limnolology, 61(2), pp. 169-175, 2002.

[14] Margaritora, F.G., Bazzanti, M., Ferrara, O., Mastrantuono, L., Seminara, M. \& Vagaggini, D., Classification of the ecological status of volcanic lakes in Central Italy. Journal of Limnology, 62(1s), pp. 49-59, 2003. 
[15] Rossi, L., Costantini, M.L., Carlino, P., di Lascio, A. \& Rossi, D., Autochthonous and allochthonous plant contributions to coastal benthic detritus deposits: A dual-stable isotope study in a volcanic lake. Aquatic Science, 72(2), pp. 227-230, 2010.

[16] Costantini, M.L., Zaccarelli, N., Mandrone, S., Rossi, D., Calizza, E. \& Rossi, L., NDVI spatial pattern and the potential fragility of mixed forested areas in volcanic lake watersheds. Forest Ecology and Management, 285, pp. 133-141, 2012.

[17] ACEA, Sustainability Report. www.annualreport2015.acea.it/sustainability/ download-area/. Accessed on: 28 Apr. 2017.

[18] Osservatorio Meteorologico di Anguillara-Sabazia, http://www.anguillarameteo.com/noaa/NOAA.php. Accessed on: 28 Apr. 2017.

[19] Rossi, D., Variazioni della linea di costa del lago di Bracciano in relazione al nuvo modello 3D bati-morfologico del fondale. Proceedings of the Sixteenth Meeting of the Italian Society of Ecology, 2006.

[20] Wantzen, K.M., Rothhaupt, K.O., Mörtl, M., Cantonati, M., László, G. \& Fischer, P., Ecological effects of water-level fluctuations in lakes: An urgent issue. Ecological Effects of Water-Level Fluctuations in Lakes, ed. Springer Netherlands, pp. 1-4, 2008.

[21] Strosnider, W.H., Hitchcock, D.R., Burke, M.K. \& Lewitus, A.J., Predicting hydrology in wetlands designed for coastal stormwater management. ASABE, paper no. 077084, pp. 1-17, 2007.

[22] Paerl, H.W., Hall, N.S. \& Calandrino, E.S., Controlling harmful cyanobacterial blooms in a world experiencing anthropogenic and climatic-induced change. Science of the Total Environment, 409(10), pp. 1739-1745, 2011.

[23] Fiorentino, F., Cicala, D., Careddu, G., Calizza, C., Jona-Lasinio, G., Rossi, L. \& Costantini, M.L., Epilithon $\delta^{15} \mathrm{~N}$ signatures indicate the origins of nitrogen loading and its seasonal dynamics in a volcanic Lake. Ecological Indicators, 79, pp. 19-27, 2017.

[24] ISTAT, 2016. http://demo.istat.it/index.html. Accessed on: 28 Apr. 2017.

[25] Ponsard, S. \& Arditi, R., What can stable isotopes $\left(\delta^{15} \mathrm{~N}\right.$ and $\left.\delta^{13} \mathrm{C}\right)$ tell about the food web of soil macro-invertebrates? Ecology, 81(3), pp. 852-864, 2000.

[26] Cole, M.L., Valiela, I., Kroeger, K.D., Tomasky, G.L., Cebrian, J., Wigand, C., McKenney, R.A., Grady, S.P. \& Carvalho da Silva, M.H., Assessment of a $\delta^{15} \mathrm{~N}$ isotopic method to indicate anthropogenic eutrophication in aquatic ecosystems. Journal of Environmental Quality, 33(1), pp. 124-132, 2004. http://dx.doi.org/10.2134/jeq2004.1240

[27] Derse, E., Knee, K.L., Wankel, S.D., Kendall, C., Berg, C.J. \& Paytan, A., Identifying sources of nitrogen to Hanalei Bay, Kauai, utilizing the nitrogen isotope signature of macroalgae. Environmental Science \& Technology, 41(15), pp. 5217-5223, 2007.

[28] Kendall, C., Elliott, E.M. \& Wankel, S.D., Tracing anthropogenic inputs of nitrogen to ecosystems. Stable Isotopes in Ecology and Environmental Science, Blackwell Publishing, pp. 375-449, 2007.

[29] Mwaura, J., Umezawa, Y., Nakamura, T. \& Kamau, J., Evidence of chronic anthropogenic nutrient within coastal lagoon reefs adjacent to urban and tourism centers, Kenya: A stable isotope approach. Marine Pollution Bulletin, forthcoming.

[30] Orlandi, L., Bentivoglio, F., Carlino, P., Calizza, E., Rossi, D., Costantini, M.L. \& Rossi, L., $\delta^{15} \mathrm{~N}$ variation in Ulva lactuca as a proxy for anthropogenic nitrogen inputs in coastal areas of Gulf of Gaeta (Mediterranean Sea). Marine Pollution Bulletin, 84(1), pp. 76-82, 2014.

[31] Hadwen, W.L., Bunn, S.E., Arthington, A.H. \& Mosisch, T.D., Within-lake detection of the effects of tourist activities in the littoral zone of oligotrophic dune lakes. Aquatic Ecosystem Health \& Management, 8(2), pp. 159-173, 2005. 
[32] Mancinelli, G., Costantini, M.L. \& Rossi, L., Top-down control of reed detritus processing in a lake littoral zone: experimental evidence of a seasonal compensation between fish and invertebrate predation. International Review of Hydrobiology, 92(2), pp. 117-134, 2007.

[33] Gartner, A., Lavery, P. \& Smit, A.J., Use of $\delta^{15} \mathrm{~N}$ signatures of different functional forms of macroalgae and filter-feeders to reveal temporal and spatial patterns in sewage dispersal. Marine Ecology Progress Series, 235, pp. 63-73, 2002.

[34] Calizza, E., Rossi, L. \& Costantini, M.L., Predators and resources influence phosphorus transfer along an invertebrate food web through changes in prey behaviour. PLoS One, 8(6), e65186, 2013.

[35] Calizza, E., Costantini, M. L., Carlino, P., Bentivoglio, F., Orlandi, L. \& Rossi, L., Posidonia oceanica habitat loss and changes in litter-associated biodiversity organization: A stable isotope-based preliminary study. Estuarine, Coastal and Shelf Science, 135, pp. 137-145, 2013.

[36] Careddu, G., Costantini, M.L., Calizza, E., Carlino, P., Bentivoglio, F., Orlandi, L. \& Rossi, L., Effects of terrestrial input on macrobenthic food webs of coastal sea are detected by stable isotope analysis in Gaeta Gulf. Estuarine, Coastal and Shelf Science, 154, pp. 158-168, 2015.

[37] Jona-Lasinio, G., Costantini, M.L., Calizza, E., Pollice, A., Bentivoglio, F., Orlandi, L., Careddu, G. \& Rossi, L., Stable isotope-based statistical tools as ecological indicator of pollution sources in Mediterranean transitional water ecosystems. Ecological Indicators, 55, pp. 23-31, 2015.

[38] Rossi, L., Costantini, M.L. \& Brilli, M., Does stable isotope analysis separate transgenic and traditional corn (Zea mays L.) detritus and their consumers? Applied Soil Ecology, 35(2), pp. 449-453, 2007.

[39] Costantini, M.L., Calizza, E. \& Rossi, L., Stable isotope variation during fungal colonisation of leaf detritus in aquatic environments. Fungal Ecology, 11, pp. 154$163,2014$.

[40] Mancinelli, G., Carrozzo, L., Costantini, M.L., Rossi, L., Marini, G. \& Pinna, M., Occurrence of the Atlantic blue crab Callinectes sapidus Rathbun, 1896 in two Mediterranean coastal habitats: Temporary visitor or permanent resident? Estuarine, Coastal and Shelf Science, 135, pp. 46-56, 2013.

[41] di Lascio, A., Rossi, L. \& Costantini, M.L., Different temperature tolerance of northern and southern European populations of a freshwater Isopod Crustacean species (Asellus aquaticus L.). Fundamental and Applied Limnology, 179(3), pp. 193-201, 2011.

[42] Wu, J., Lin, L., Gagan, M.K., Schleser, G.H. \& Wang, S., Organic matter stable isotope $\left(\delta^{13} \mathrm{C}, \delta^{15} \mathrm{~N}\right)$ response to historical eutrophication of Lake Taihu, China. Hydrobiologia, 563(1), pp. 19-29, 2006.

[43] Titlyanov, E.A., Kiyashko, S.I., Titlyanova, T.V., Huyen, P.V. \& Yakovleva, I.M., Identifying nitrogen sources for macroalgal growth in variously polluted coastal areas of southern Vietnam. Botanica Marina, 54(4), pp. 367-376, 2011.

[44] Lin, H.J., Wu, C.Y., Kao, S.J., Kao, W.Y. \& Meng, P.J., Mapping anthropogenic nitrogen through point sources in coral reefs using $\delta^{15} \mathrm{~N}$ in macroalgae. Marine Ecology Progress Series, 335, pp. 95-109, 2007. 